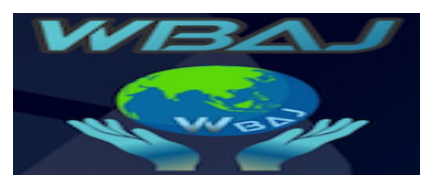

Volume 1 Issue 2, Desember 2019

http:/ / ejournal.unsub.ac.id/index.php/bisnis

\title{
Pengaruh Kualitas Pelayanan Terhadap Loyalitas Pelanggan Pada Sari Ater Hotel \& Resort Subang
}

\author{
Nelli Sulistiana ${ }^{1}$ \\ BAPEDA Kabupaten Subang \\ nellisulistiana04@gmail.com
}

Iwan Henri Kusnadi ${ }^{2}$

Fakultas Ilmu Administrasi Universitas Subang iwanhenri01@gmail.com

Ade Nawawi ${ }^{3}$

Fakultas Ilmu Administrasi Universitas Subang

adenawawi15.an@gmail.com

\begin{abstract}
Abstrak
Tujuan peneliti melakukan penelitian ini adalah untuk mengetahui seberapa besar tingkat kualitas pelayanan dan tingkat loyalitas pelanggan pada Sari Ater Hotel E Resort Subang, serta untuk mengetahui seberapa besar pengaruh kualitas pelayanan terhadap loyalitas pelanggan. Dari hasil penelitian bahwa tingkat kualitas pelayanan pada Sari Ater Hotel $\mathcal{E}$ Resort Subang berada pada tingkat cukup tinggi, dan untuk tigkat loyalitas pelanggannya berada pada tingkat cukup tinggi pula. Adapun pengaruh kualitas pelayanan $(\mathrm{X})$ terhadap loyalitas pelanggan $(\mathrm{Y})$ memiliki pengaruh positif signifikan yakni sebesar 70,4\%, sedangkan 29,6\% sisanya dipengaruhi oleh faktor lain yang tidak diteliti oleh peneliti.
\end{abstract}

Kata kunci: Kualitas Pelayanan, Loyalitas Pelanggan.

\begin{abstract}
The objective of the researcher conducting this research is to find out how much the level of service quality and level of customer loyalty at Sari Ater Hotel E Resort Subang, and to find out how much influence the quality of service on customer loyalty. From the results of the study that the level of service quality at Subang Sari Ater Hotel $\mathcal{E}$ Resort is at a fairly high level, and for the level of customer loyalty is at a fairly high level too. The effect of service quality (X) on customer loyalty $(Y)$ has a significant positive effect of $70.4 \%$, while the remaining $29.6 \%$ is influenced by other factors not examined by researchers.
\end{abstract}

Keywords: Service Quality, Customer Loyalty 


\section{Pendahuluan}

Perkembangan ekonomi memberikan pengaruh terhadap aspek pemasaran. Manajemen perusahaan dituntut untuk mempunyai konsep pemasaran yang tepat agar senantiasa mampu mengatasi persaingan dalam dunia bisnis. Adanya persaingan bisnis ini memunculkan ide-ide baru untuk berinovasi dalam membangun suatu usaha atau menyediakan barang dan jasa agar lebih memiliki keunggulan bahkan ciri khas tersendiri dalam sektor pariwisata. Pada umumnya, setiap perusahaan menganut sistem pemasaran yang berorientasi kepada konsumen yaitu sistem pemasaran yang senantiasa berusaha untuk memenuhi kebutuhan dan keinginan konsumen. Di era persaingan yang semakin kompetitif, setiap perusahaan semakin menyadari bahwa pentingnya loyalitas pelanggan untuk menjamin kelangsungan bisnisnya. Loyalitas pelanggan menurut Tjiptono (2000:110) adalah komitmen pelanggan terhadap suatu merek, toko atau pemasok berdasarkan sifat positif dalam pembelian jangka panjang. Adapun dimensi loyalitas pelanggan menurut Griffin Jill (2005: 31) yaitu: melakukan pembelian berulang secara teratur, membeli antar lini produk dan jasa, mereferensikan kepada orang lain dan menunjukkan kekebalan terhadap tarikan dari pesaing. Pelanggan merupakan seseorang yang terus-menerus dan berulangkali datang ke suatu tempat yang sama untuk memuaskan keinginannya dengan memiliki suatu produk atau mendapatkan suatu jasa dan membayar produk atau jasa tersebut. Loyalitas pelanggan sangat penting artinya bagi perusahaan yang menjaga kelangsungan bisnisnya. Pelanggan yang setia adalah mereka yang puas dengan produk atau jasa dan pelayanan tertentu, sehingga mempunyai antusiasme untuk memperkenalkannya kepada siapapun. Perusahaan berharap agar dapat mempertahankan pelanggan dalam waktu yang lama. Sebab apabila perusahaan mempunyai pelanggan yang loyal maka pelanggan tersebut tidak hanya akan menggunakan produk atau jasa secara terusmenerus, tetapi dengan sendirinya pelanggan akan merekomendasikan kepada orang lain sesuai dengan apa yang dirasakan. Pelanggan yang loyal memiliki kecenderungan yang lebih rendah untuk berpindah merek kepada produk atau jasa pesaing. Seorang pelanggan itu dapat dikatakan sebagai pelanggan yang loyal apabila seorang pelanggan tersebut memiliki komitmen yang kuat untuk membeli atau menggunakan barang tersebut secara rutin. Perkembangan dunia bisnis saat ini mengalami peningkatan yang cukup tinggi. Pariwisata merupakan salah satu sektor industri terbesar dan tercepat perkembangannya di dunia. Dalam perkembangannya, sektor pariwisata ini turut berperan penting dalam mendukung pertumbuhan perekonomian nasional dan memegang peranan penting dalam menumbuhkan perekonomian daerah, oleh karena itu mayoritas daerah di Indonesia bersaing dalam memperkenalkan potensi kepariwisataannya.

Objek wisata merupakan produk jasa yang ditawarkan oleh suatu perusahaan jasa dengan harapan agar konsumen datang untuk berkunjung dan menikmati objek wisata yang ditawarkan. Untuk dapat menarik loyalitas pelanggan, pengelola harus 
dapat memberikan pelayanan terbaik untuk menciptakan loyalitas pelanggan. Secara umum industri jasa memiliki karakteristik yang berbeda, karena pada industri jasa produk yang dihasilkan tidak berwujud secara fisik. Karakteristik yang berbeda pada industri jasa seringkali menyebabkan pelanggan sulit untuk melakukan evaluasi terhadap kualitas sehingga ukuran kualitas sering mengacu pada persepsi pelanggan. Tidak jarang persepsi pelanggan terbentuk berdasarkan servicescape, yaitu bukti fisik yang seolah-olah membungkus pelayanan yang bersangkutan dan mencerminkan suatu citra eksternal dari apa yang ada didalamnya. Kualitas pelayanan terbaik merupakan suatu profit strategy untuk menikmati lebih banyak konsumen baru, mempertahankan konsumen yang ada, dan menghindari kaburnya konsumen. Apabila pelayanan yang diterima atau dirasakan sesuai dengan harapan, maka kualitas pelayanan yang diterima atau dirasakan sesuai dengan yang diharapkan, maka kualitas pelayanan dipersepsikan baik dan memuaskan. Kualitas pelayanan menurut Kotler (dalam Alma, 2007:286) mengungkapkan bahwa kualitas pelayanan adalah suatu cara kerja perusahaan yang berusaha mengadakan perbaikan mutu secara terus-menerus terhadap proses, produk, dan servis ysng dihasilkan perusahaan. Adapun dimensi kualitas pelayanan menurut Tjiptono Fandy (2016:137) yaitu: Kehandalan (reliability), daya tanggap (responsiveness), jaminan (assurance), empati (empathy), dan bukti fisik (tangibles).

Potensi kepariwisataan di Provinsi Jawa Barat sangat banyak dan beragam. Selain itu, Jawa Barat memiliki berbagai macam destinasi wisata yang tersebar di masing-masing kabupaten. Keberadaan destinasi wisata tersebut berdampak pada tingkat kunjungan wisatawan domestik yang meningkat setiap tahunnya. Wisata alam menjadi jenis wisata yang paling banyak diminati. Kabupaten Subang merupakan salah satu kabupaten di Jawa Barat yang memiliki sumber daya wisata. Mulai dari daerah pegunungan, berbukit, hingga dataran rendah, memiliki objek dan daya tarik wisata Alam, objek dan daya tarik Budaya serta objek dan daya tarik Minat Khusus. Berdasarkan keragaman Objek dan Daya Tarik Wisata (ODTW) yang ada, Kabupaten Subang menjadi salah satu yang memiliki potensi untuk dikembangkan. Keindahan alam dan kekayaan budaya yang ada di Kabupaten Subang dapat menjadikan kabupaten ini sebagai tujuan utama wisatawan ketika berkunjung ke Jawa Barat. Keragaman potensi membuat objek wisata di Kabupaten Subang menjadi ramai dikunjungi wisatawan. Kabupaten Subang memiliki tempat-tempat wisata yang menarik. Salah satu tujuan favorit wisatawan berkunjung ke Kabupaten Subang adalah daerah Ciater. Hal ini karena wilayah Ciater memiliki daya tarik yang cukup unik yaitu daerah yang memiliki banyak mata air panas alami yang bersumber dari kawah Gunung Tangkuban Perahu yang terletak tidak jauh dari daerah Ciater. Sehingga banyak pengusaha yang membuat pemandian air panas sebagai peluang bisnis. Adanya manfaat kesehatan yang terkandung pada sumber air panas mampu menjadi daya tarik pengunjung. Adanya pencegahan dan penyembuhan berbagai macam penyakit kulit dengan menggunakan sumber air panas alami tersebut konsumen tidak akan mengalami kesulitan untuk mendapatkan khasiat atau manfaat air panas dengan cara berkunjung ke Sari Ater Hotel \& Resort. 


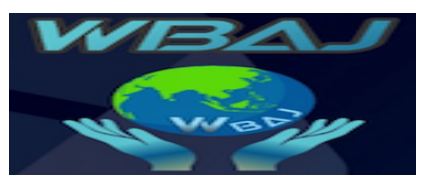

Volume 1 Issue 2, Desember 2019

http://ejournal.unsub.ac.id/index.php/bisnis

Sari Ater Hotel $\mathcal{E}$ Resort juga menyediakan berbagai fasilitas seperti pemandian air panas, restoran, hotel untuk para turis domestik ataupun asing. Sari Ater Hotel $\mathcal{E}$ Resort dituntut untuk lebih memperhatikan kualitas pelayanan terhadap pengunjung, dengan menetapkan harga yang terjangkau, kualitas pelayanan, kualitas kebersihan, menjadikan objek wisata yang sesuai dengan keinginan masyarakat. Sesuai perkembangan, maka sarana dan prasarana serta paket wisata yang ada di Sari Ater Hotel $\mathcal{E}$ Resort juga berkembang sesuai dengan kebutuhan yang akan datang. Saat ini perusahaan terus berupaya menyajikan segala kemudahan dan fasilitas bagi pengunjung baik wisatawan nusantara maupun wisatawan mancanegara. Sari Ater Hotel $\mathcal{E}$ Resort menyadari persaingan yang semakin tinggi di bidang pariwisata ini, maka secara terus-menerus diwajibkan memberikan pelayanan yang lebih baik dari pada para pesaing yang ada. Dengan kualitas pelayanan jasa yang kurang baik menyebabkan terjadinya penurunan jumlah pengunjung pada Sari Ater Hotel $\mathcal{E}$ Resort. Hal ini membuktikan bahwa terjadi kesenjangan antara teori dengan fakta yang ada, dapat dilihat dari tabel 1.

Tabel 1

Jumlah Kunjungan pada Sari Ater Hotel E Resort Ciater Subang Periode Tahun 2012 $-2018$

\begin{tabular}{|c|c|r|r|r|}
\hline \multirow{2}{*}{ No } & \multirow{2}{*}{ Tahun } & \multicolumn{2}{|c|}{ Jenis Pengunjung } & \multirow{2}{*}{ Jumlah Pengunjung } \\
\cline { 3 - 4 } & & Domestik & Asing & \\
\hline 1 & 2012 & 1.842 .599 & 12.493 & $\mathbf{1 . 8 5 5 . 0 9 2}$ \\
\hline 2 & 2013 & 1.674 .249 & 28.437 & $\mathbf{1 . 7 0 2 . 6 8 6}$ \\
\hline 3 & 2014 & 1.655 .497 & 33.468 & $\mathbf{1 . 6 8 8 . 9 6 5}$ \\
\hline 4 & 2015 & 1.665 .017 & 16.869 & $\mathbf{1 . 6 8 1 . 8 8 6}$ \\
\hline 5 & 2016 & 1.437 .356 & 41.800 & $\mathbf{1 . 4 7 9 . 1 5 6}$ \\
\hline 6 & 2017 & 1.401 .181 & 24.679 & $\mathbf{1 . 4 2 5 . 8 6 0}$ \\
\hline 7 & 2018 & 1.374 .850 & 14.115 & $\mathbf{1 . 3 8 8 . 9 6 5}$ \\
\hline \multicolumn{2}{|c|}{ Total } & $\mathbf{1 1 . 3 6 4 . 8 6 4}$ & $\mathbf{1 7 1 . 8 6 1}$ & $\mathbf{1 1 . 2 2 2 . 6 1 0}$ \\
\hline
\end{tabular}

Sumber: HRD Sari Ater Hotel $\mathcal{E}$ Resort Subang.

Berdasarkan penjajagan awal yang didapatkan oleh penulis bahwa Sari Ater Hotel $\mathcal{E}$ Resort Subang mengalami penurunan jumlah pengunjung. Hal ini menunjukkan bahwa masih rendahnya loyalitas pelanggan terlihat dari indikator sebagai berikut:

1. Berkurang rata-rata jumlah pembelian berulang. Terdapat keluhan terkait tiket masuk yang kurang efisien karena pengelola menyediakan banyak tiket masuk, dimana tiket masuk yang ditawarkan belum termasuk tiket tembusan ke kolam rendam. Harga tiket masuk yang relatif cukup mahal. Harga yang di tawarkan termasuk dari kalangan menengah ke atas.

\section{Tabel 2}




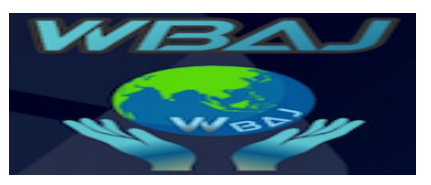

Volume 1 Issue 2, Desember 2019

http:/ / ejournal.unsub.ac.id/index.php/bisnis

Daftar Harga Masuk Wisata Sari Ater Hotel \& Resort Subang

\begin{tabular}{|c|c|c|}
\hline \multicolumn{3}{|c|}{ Tiket Masuk } \\
\hline \multicolumn{3}{|c|}{ Gerbang Utama } \\
\hline Tiket & Weekday & Libur Nasional \\
\hline Perorangan & Rp. 30.000 & Rp. 35.000 \\
\hline Motor & Rp. 20.000 & Rp. 25.000 \\
\hline Mobil & Rp. 30.000 & Rp. 35.000 \\
\hline Bus/Truck & Rp. 42.000 & Rp. 45.000 \\
\hline \multicolumn{3}{|c|}{ Tiket Kolam Rendam \& Kamar Rendam } \\
\hline Tiket & Weekday & Libur Nasional \\
\hline Kolam Rendam Mayangsari & Rp. 45.000 & Rp. 50.000 \\
\hline $\begin{array}{l}\text { Kolam Rendam } \\
\text { Wangsadipa }\end{array}$ & Rp. 25.000 & Rp. 27.000 \\
\hline Kolam Rendam Pulosari & Rp.. 28.000 & Rp. 30.000 \\
\hline Kolam Rendam Leuwi Sari & Rp. 14.000 & Rp. 14.000 \\
\hline Kamar Rendam & Rp. 60.000 & Rp. 60.000 \\
\hline Paket Mayangsari & Rp. 65.000 & Rp. 65.000 \\
\hline Paket Kimannis & Rp. 75.000 & Rp. 75.000 \\
\hline \multicolumn{3}{|c|}{ Tiket Permainan } \\
\hline Nama Permainan & \multicolumn{2}{|c|}{ Harga } \\
\hline Komedi Putar & \multicolumn{2}{|c|}{ Rp. 8.000} \\
\hline Sepeda Air & \multicolumn{2}{|c|}{ Rp. 10.000} \\
\hline Perahu Dayung & \multicolumn{2}{|c|}{ Rp. 10.000} \\
\hline Kereta Mini & \multicolumn{2}{|c|}{ Rp. 8.000} \\
\hline Water Bll & \multicolumn{2}{|c|}{ Rp. 25.000} \\
\hline Dream Zone & \multicolumn{2}{|c|}{ Rp. 16.000} \\
\hline Wall Climbing 1 Putaran & \multicolumn{2}{|c|}{ Rp. 20.000} \\
\hline Wall Climbing 2 Putaran & \multicolumn{2}{|c|}{ Rp. 25.000} \\
\hline Trampolin & \multicolumn{2}{|c|}{ Rp. 20.000} \\
\hline Panahan 6 panahan & \multicolumn{2}{|c|}{ Rp. 10.000} \\
\hline Panahan 12 panahan & \multicolumn{2}{|c|}{ Rp. 15.000} \\
\hline
\end{tabular}

Sumber: HRD Sari Ater Hotel E Resort Subang.

2. Belum optimal dalam menunjukan kekebalan produk jasa yang ditawarkan dalam persaingan. Fenomena pariwisata yang semakin berkembang. Sari Ater Hotel $\mathcal{E}$ Resort merupakan tempat wisata alam. Wisata Alam harus mampu menunjukan kekebalan nya tanpa merusak keasrian alam.

\section{Kerangka Teori}




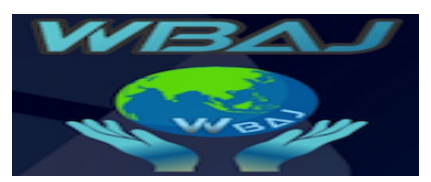

Volume 1 Issue 2, Desember 2019

http:/ / ejournal.unsub.ac.id/index.php/bisnis

\section{a. Kualitas Pelayanan}

Menurut Kotler (2003) mendefinisikan kualitas sebagai keseluruhan ciri dan karakteristik produk atau jasa yang mendukung kemampuan untuk memuaskan kebutuhan. Pengertian kualitas dapat pula dibedakan menurut pandangan produsen dan konsumen (Kotler, 2003). Definisi kualitas menurut produsen adalah kesesuaian terhadap spesefikasi, dalam hal ini produsen memberikan toleransi tertentu yang dispesifikasi untuk dimensi-dimensi kritis dari tiap bagian yang dihasilkan. Adapun dari sudut pandang konsumen, kualitas berarti nilai, yaitu seberapa baik suatu produk atau jasa menyajikan suatu tujuan yang dimaksudkan dengan tingkat harga yang bersedia dibayar oleh konsumen. Definisi kualitas menurut para ahli tersebut pada dasarnya mempunyai beberapa kesamaan, yaitu: kualitas meliputi usaha memenuhi atau melebihi harapan pelanggan, kualitas mencakup produk, jasa, manusia, proses dan lingkungan serta kualitas merupakan kondisi yang selalu berubah, yakni apa yang dianggap merupakan sesuatu yang berkualitas saat ini mungkin dianggap kurang berkualitas pada masa mendatang (Kotler, 2003).

\section{b. Pengertian Kualitas Pelayanan}

Menurut Kotler (2008:83) mengungkapkan bahwa pelayanan adalah setiap tindakan atau kegiatan yang dapat ditawarkan oleh suatu pihak kepada pihak lain, yang pada dasarnya tidak berwujud dan tidak mengakibatkan kepemilikan apapun. Menurut Lena Ellitan dan Lina Anatan (2007:115) mengungkapkan bahwa pelayanan adalah aktivitas-aktivitas yang tidak terwujud dan merupakan objek utama dari transaksi yang dirancang untuk memeberikan kepuasan kepada pelanggan. Dari definisi diatas dapat disimpulkan bahwa pelayanan merupakan suatu kegiatan untuk memenuhi kebutuhan dan keinginan pelanggan yang pada hakekatnya bersifat tidak berwujud.Menurut Kotler (dalam Alma, 2007:286) mengungkapkan bahwa kualitas pelayanan adalah suatu cara kerja perusahaan yang berusaha mengadakan perbaikan mutu secara terus menerus terhadap proses, produk dan servis yang dihasilkan perusahaan.

Menurut Wyckof (dalam Tjiptono Fandy, 2014:268), kualitas jasa merupakan tingkat keunggulan (excellence) yang diharapkan dan pengendalian atas keunggulan tersebut untuk memenuhi keinginan pelanggan. Berdasarkan pandangan tersebut diatas tampak bahwa kualitas pelayanan merupakan suatu tindakan atau aktivitas yang mengadakan perbaikan mutu agar bisa dinikmati manfaatnya dan sebagai usaha pemenuhan dari keinginan pelanggan serta ketetapan penyampaian jasa dalam rangka memenuhi harapan pelanggan.

Menurut pakar pemasaran yaitu Parasuraman, Zeithmal dan Berry (dalam Tjiptono Fandy, 2016:136) mereka berhasil melakukan penelitian khusus terhadap beberapa jenis jasa dan berhasil mengidentifikasi 10 (sepuluh) faktor utama yang menentukan kualitas pelayanan. Kesepuluh faktor tersebut meliputi:

1. Reliability, mencakup dua hal pokok, yaitu konsistensi kerja (perdormance) dan kemampuan untuk dipercaya (dependability). Hal ini berarti perusahaan yang bersangkutan memenuhi janjinya, misalnya menyampaikan jasanya sesuai jadwal yang disepakati. 
2. Responsiveness, yaitu kemauan atau kesiapan para karyawan untuk memberikan jasa yang dibutuhkan pelanggan.

3. Competence, artinya setiap orang dalam suatu perusahaan memiliki keterampilan dan pengetahuan yang dibutuhkan agar dapat memberikan jasa tertentu.

4. Access, meliputi kemudahan untuk dihubungi dan ditemui. Hal ini berarti lokasi fasilitas jasa yang mudah dijangkau, waktu menunggu yang tidak terlalu lama, saluran komunikasi perusahaan mudah dihubungi, dan lain-lain.

5. Courtesy, meliputi sikap sopan santun, respek, perhatian,dan keramahan yang dimiliki para contact personnel (seperti resepsionis, teller, operator telepon, dan lain-lain).

6. Communication, artinya memberikan informasi kepada pelanggan dalam bahasa yang dapat mereka pahami, serta selalu mendengar saran dan keluhan pelanggan.

7. Credibility, yaitu sifat jujur dan dapat dipercaya. Kredibilitas mencakup nama perusahaan, reputasi perusahaan, karakteristik contact personnel, dan interaksi dengan pelanggan.

8. Security, yaitu aman dari bahaya, risiko, atau keraguan. Aspek ini meliputi keamana secara fisik, keamanan finansial, dan kerahasiaan.

9. Understanding, yaitu usaha untuk memahami kebutuhan pelanggan.

10. Tangibles, yaitu bukti fisik dari jasa, bias berupa fasilitas fisik, peralatan yang digunakan, representasi fisik dari jasa misalnya unit komputer yang digunakan.

Adapun dimensi kualitas pelayanan yang akan digunakan dalam penelitian ini adalah dimensi menurut Tjiptono (2016:137) yaitu :

1. Kehandalan (reliability), yakni kemampuan memberikan layanan yang dijanjikan dengan segera, akurat, dan memuaskan

2. Daya tanggap (responsiveness), yaitu keinginan para staff untuk membantu para pelanggan dan memberikan layanan daya tanggap.

3. Jaminan (assurance), mencakup pengetahuan, kompetensi, kesopanan, dan sifat dapat dipercaya yang dimiliki para staff; bebas dari bahaya, risiko atau keraguraguan.

4. Empati (empathy), meliputi kemudahan dalam menjalin relasi, komunikasi yang baik, perhatian pribadi, dan pemahaman atas kebutuhan individual pelanggan.

5. Bukti fisik (tangibles), meliputi fasilitas fisik, perlengkapan, pegawai, dan sarana komunikasi.

Dimensi-dimensi kualitas jasa yang telah disebutkan harus dapat diramu dengan baik karena apabila tidak, hal tersebut dapat menimbulkan kesenjangan antara perusahan dengan pelanggan.Menurut Parasuraman, Zeithaml dan Berry dalam Fandy Tjiptono \& Gregorius Chandrra (2016) dalam penelitiannya mengenai customer-perceived quality pada industri jasa, mengidentifikasi lima kesenjangan (gap) yang menyebabkan kegagalan penyampaian jasa, yaitu :

a) Kesenjangan persepsi manajemen

b) Kesenjangan persepsi manajemen yaitu adanya perbedaan antara penilaian pelayanan menurut pengguna jasa dan persepsi manajemen mengenai harapan 
pengguna jasa. Kesenjangan ini terjadi karena kurangnya orientasi penelitian pemasaran, pemanfaatan yang tidak memadai atas temuan penelitian, kuranngnya interaksi antara pihak manajemen dengan pelanggan, komunikasi dari bawah keatas kurang memadai, serta terlalu banyaknya tingkatan manajemen.

c) Kesenjangan spesifikasi kualitas

d) Kesenjangan spesifikasi kualitas yaitu kesenjangan antara persepsi manajemen mengenai harapan pengguna jasa dan spesifikasi kualitas jasa. Kesenjangan terjadi antara lain karena tidak memadainya komitmen manajemen terhadap kualitas jasa, persepsi mengenai ketidaklayakan, tidak memadainya standarisasi tugas, dan tidak adanya penyusunan tujuan.

e) Kesenjangan penyampaian jasa

f) Kesenjangan ini disebabkan oleh faktor-faktor : (1) ambiguitas peran yaitu sejauh mana karyawan dapat melakukan tugas sesuai dengan harapan manajer tetapi memuaskan pelanggan, (2) konflik peran yaitu sejauh mana pegawai meyakini bahwa mereka tidak memuaskan semua pihak, (3) kesesuaian pegawai dengan tugas yang harus dikerjakannya, (4) kesesuaian teknologi yang digunakan pegawai, (5) sistem pengendalian dari atasan, yaitu tidak memadainya sistem penilaian dan sistem imabalan, (6) perceived control yaitu sejauh mana pegawai merasakan kebebasan atau fleksibilitas untuk menentukan cara pelayanan, (7) team work yaitu sejauh mana pegawai dan manajemen merumuskan tujuan bersama di dalam memuaskan pelanggan secara bersama-sama dan terpadu.

g) Kesenjangan komunikasi pemasaran

h) Kesenjangan ini terjadi karena (1) tidak memadainya komunikasi horizontal, (2) adanya kecenderungan untuk memberikan janji yang berlebihan. Yang dihadapi perusahaan adalah apabila janji yang diberikan tidak dapat dipenuhi.

i) Kesenjangan dalam pelayanan yang dirasakan

j) Kesenjangan dalam pelayanan yang dirasakan yaitu perbedaan persepsi antara jasa yang dirasakan dan yang diharapkan oleh pelanggan. Jika keduanya terbukti sama, maka perusahaan akan memperoleh citra dan dampak positif. Namun bila yang diterima lebih rendah dari yang diharapkan, maka kesenjangan ini akan menimbulkan permasalahan bagi perusahaan.

\section{c. Prinsip-prinsip Kualitas Pelayanan}

Dalam rangka menciptakan gaya manajemen dan lingkungan yang kondusif bagi organisasi jasa untuk menyempurnakan kualitas, organisasi bersangkutan harus mampu mengimplementasikan enam prinsip utama yang berlaku baik bagi perusahaan manufaktur maupun organisasi jasa. Menurut Wolkins dalam Tjiptono Fandy \& Gregorius Chandrra (2016:141) enam prinsip tersebut, yaitu :

1) Kepemimpinan

Manajemen puncak harus memimpin dan mengarahkan organisasinya dalam upaya peningkatan kualitas. Tanpa adanya kepemimpinan dari manajemen puncak, usaha peningkatan kualitas hanya akan berdampak kecil.

2) Pendidikan 
Semua karyawan, mulai dari manajer puncak sampai karyawan oprasional wajib mendapatkan pendidikan mengenai kualitas. Aspek-aspek yang perlu mendapatkan penekanan dalam pendidikan tersebut antara lain konsep kualitas sebagai strategi bisnis, alat dan teknik implementasi strategi kualitas, dan peranan eksklusif dalam implementasi strategi kualitas.

3) Perencanaan Strategik

Proses perencanaan strategik harus mencakup pengukuran dan tujuan kualitas yang dipergunakan dalam mengarahkan untuk mencapai visi dan misinya.

4) Review

Proses review merupakan satu-satunya alat yang paling efektif bagi manajemen untuk mengubah perilaku organisasional. Proses ini menggambarkan mekanisme yang menjamin adanya perhatian terus-menerus terhadap upaya mewujudkan sasaran-sasaran kualitas.

5) Komunikasi

Implementasi strategi kualitas dalam organisasi dipengaruhi oleh proses komunikasi organisasi, baik dengan karyawan, pelanggan, maupun stakeholder lainnya (seperti pemasok, pemegang saham, pemerintah, masyarakat sekitar, dan lain-lain).

6) Total Human Reward

Reward dan recognition merupakan aspek krusial dalam implementasi strategi kualitas jasa. Setiap karyawan berprestasi perlu diberi imbalan dan prestasinya harus diakui.

\section{d. Loyalitas Pelanggan}

Menurut Kotler (2005:18), menyebutkan bahwa loyalitas pelanggan adalah suatu pembelian ulang yang dilakukan oleh seorang pelanggan karena komitmen pada suatu merek atau perusahaan. Sedangkan menurut Nugroho (dalam Kotler, 2005:18) menyatakan bahwa: Loyalitas pelanggan didefinisikan sebagai suatu ukuran kesetiaan dari pelanggan dalam menggunakan suatu merek produk atau jasa pada kurun waktu tertentu pada suatu situasi dimana banyak pilihan produk ataupun jasa yang dapat memenuhi kebutuhannya dan pelanggan memiliki kemampuan mendapatkannya. Berdasarkan uraian diatas bahwa loyalitas pelanggan merupakan suatu kesetiaan pelanggan terhadap suatu merek produk atau jasa sehingga terjadi pembelian berulang dan tidak berpindah. Menurut Griffin (2005:35) adapun proses atau tahapan terbentuknya loyalitas pelanggan yang terbagi dalam tujuh tahap, yaitu:

1. Suspect, adalah orang yang mungkin membeli produk atau jasa. Disebut sebagai Suspect, karena tamu akan melakukan pembelian namun belum tentu mengetahui perusahaan dan produk atau jasa yang ditawarkan.

2. Prospect, adalah orang yang memiliki kebutuhan terhadap produk atau jasa tertentu, dan mempunyai kemampuan untuk membelinya artinya tahap ini tamu telah mengetahui keberadaan perusahaan secara produk dan jasa, namun belum pernah melakukan pembelian. 
3. Disqualified, adalah tamu yang tidak membutuhkan produk atau jasa yang ditawarkan, atau tahap ini disebut sebagai tahap dimana tamu tidak mempunyai kemampuan untuk melakukan pembelian.

4. Frist time customers, adalah tamu yang membeli produk atau jasa untuk pertama kalinya, namun mereka juga masih rawan utuk melakukan pembelian yang sama pada perusahaan asing.

5. Repeat customers, adalah tamu yang telak membeli produk atau jasa dari dua kali atau lebih, bahkan bisa jadi mereka telah melakukan pembelian dua jenis produk atau jasa yang berbeda dalam waktu yang berbeda pula.

6. Clients, adalah tamu yang membeli semua produk atau jasa yang mereka butuhkan secara teratur. Pada tahap ini hubungan dengan tamu sudah terjalin cukup kuat dan telah berlangsung dalam waktu yang lama, sehingga tamu tidak terpengaruh dengan rangsangan produk atau jasa dari pesaig.

7. Advocaters, adalah tamu yang membeli semua produk atau jasa yang mereka butuhkan secara teratur, serta mendorong orang lain untuk ikut melakukan pembelian pada perusahaan yang sama dengannya.

\section{e. Faktor- Faktor yang mempengaruhi Loyalitas Pelanggan}

Seorang konsumen akan menjadi pelanggan yang loyal Dalam membangun dan karena adanya beberapa faktor-faktor yang menentukan loyalitas terhadap suatu produk atau jasa. Dalam membangun dan memperhatikan faktor-faktor yang mempengaruhinya. Menurut Griffin Jill (2005) faktor-faktor yang mempengaruhi loyalitas pelanggan adalah perhatian (caring), kepercayaan (trust), perlindungan (lengh of patronage), dan kepuasan akumulatif (overall satifaction).

1) Faktor pertama, yaitu perhatian (caring), perusahaan harus dapat melihat dan mengatasi segala kebutuhan, harapan, maupun permasalahan yang dihadapi oleh pelanggan. Dengan perhatiam itu, pelanggan akan menjadi puas terhadap perusahaan dan melakukan transaksi ulang dengan perusahaan, dan pada akhirnya mereka akan menjadi pelanggan perusahaan yang loyal. Semakin perusahaan menunjukkan perhatiannya, maka semakin besar loyalitas pelanggan yang akan mucul.

2) Faktor kedua, yaitu kepercayaan (trust), kepercayaan timbul dari suatu proses yang lama sampai kedua belakh pihak saling mempercayai. Apabila kepercayaan sudah terjalin di antara pelanggan dan perusahaan, maka usaha untuk membinanya akan lebih mudah, hubungan perusahaan dengan pelanggan tercermin dari tingkat kepertcayaan (trust) para pelanggan. Apabila tingkat kepercayaan tinggi, maka hubungan perusahaan dengan pelanggan akan menjadi kuat. Slah satu cara yang dapat dilakukan perusahaan dalam membina hubungan dengan pelanggan, yaitu segala jenis produk atau jasa yang dihasilkan perusahaan harus memiliki kualitas atau kesempurnaan seperti yang seharusnya atau sebagaimana dijanjikan, sehingga pelanggan tidak merasa tertipu, yang mana hal ini dapat mengakibatkan pelanggan berpindak ke produk pesaing. 
3) Faktor ketiga, yaitu perlindungan (lengh of patronage), perusahaan harus dapat memberikan perlindungan kepada pelangganya, baik berupa kualitas produk, pelayanan, complain ataupun layanan purna jual. Dengan demikian, pelanggan tidak khawatir perusahaan dalam melakukan transaksi dan berhubungan dengan perusahaan memberikan perlindungan yang mereka butuhkan.

4) Faktor keempat, yaitu kepuasan akumulatif (overall satifaction), kepuasan akumulatif adalah keseluruhan penilaian berdasarkan total pembelian dan konsumsi atas barang atau jasa pada suatu periode tetentu. Kepuasan akumulatif ditentukan oleh berbagai komponen seperti kepuasan terhadap sikap agen (service provider) dan kepuasan terhadap perusahaan itu sendiri. Oleh karena itu, perusahaan harus dapat memberikan rasa puas terhadap para pelanggan dalam melakukan segala transaksi dengan perusahaan, sehinggan dalam hal ini perusahaan harus memperhatikan dan meningkatkan fungsi dan kegunaan dari segala fasilitas dan sumber daya yang dimiliki agar pelanggan dapat memanfaatkannya kapan saja dan dimana saja.

\section{Metode Penelitian}

Dalam penelitian ini, penulis akan menggunakan metode penelitian kuantitatif dengan pendekatan Deskriptif dan Eksplanasi. Menurut Sugiono (2012:29), "Penelitian deskriptif adalah penelitian yang dilakukan untuk mengetahui nilai variabel mandiri, baik satu variabel atau lebih (independen) tanpa membuat perbandingan, atau menghubungkan dengan variabel yang lain". Metode eksplanasi adalah suatu metode penelitian yang menggambarkan dua variabel yang di teliti, yaitu variabel bebas dan variabel terikat yang kemudian menjelaskan hubungan atau pengaruh kedua variabel tersebut. Metode penelitian kuantitatif dapat diartikan sebagai metode penelitian yang berlandaskan pada filsafat positivisme, digunakan untuk meneliti pada populasi atau sampel tertentu, teknik pengambilan sampel pada umumnya dilakukan secara random, pengumpulan data menggunakan instrumen penelitian, analisis data bersifat kuantitatif/statistik dengan tujuan untuk menguji hipotesis yang telah ditetapkan (Sugiyono, 2014:13).

\section{Hasil dan Pembahasan}

\section{a. Deksripsi Objek Penelitian}

Desa Ciater yang terletak di Selatan Ibu Kota Kabupaten Subang pada mulanya adalah sebuah hutan belantara yang sangat subur, karenanya sangat memungkinkan 
sekali untuk dijadikan daerah perkebunan. Melihat kondisi demikian maka Belanda merencanakan membuat perkebunan karet dan teh. Untuk membuka hutan belantara merupakan persoalan yang tidak mudah pada saat itu, disebabkan mitos masyarakat terhadap kekuatan siluman yang dapat mengganggu manusia, tapi tanpa diduga ada seorang yang bersedia membuka daerah hutan itu, dia adalah Embah Ebos (sekarang dikenal dengan sebutan Eyang Ebos) untuk keterangan ini dianggap bahwa Eyang Ebos benar yang membuka hutan untuk perkebunan dan Desa Ciater sekarang, sebab tidak mungkin ada perkebunan kalau belum ada penghuninya. Setelah hutan belantara berubah menjadi sebuah perkampungan yang sekarang dikatakan Ciater, terjadilah musim kemarau yang mengerikan selama berbulan-bulan, konon ada yang mengatakan hujan tidak turun selama 8 bulan. Embah Ebos dan masyarakat berdoa kepada Allah SWT agar dikaruniai air, doa tersebut dikabulkan sehingga memancarlah air dari sebuah pohon bambu yang dinamakan POHON ATER, ada sumber yang mengatakan bahwa seorang yang bernama Embah Tajimalela memotong pohon ater, maka keluar air dari bawah pohon tersebut. Dari cerita itu orang mengatakan daerah yang dibuka Embah Ebos disebut Ciater, artinya air yang memancar dari bawah pohon ater, sampai sekarang air dari bawah pohon ater tersebut tidak pernah mengalami kekeringan meskipun dimusim kemarau yang panjang.

Pada awalnya tempat wisata air panas alam Ciater yang sekarang lebih dikenal dengan sebutan SARI ATER Hot Spring Resort Hotel dan Rekreasi adalah tempat pemandian yang biasa dipergunakan oleh masyarakat sekitar Desa Ciater, Palasari dan Nagrak. Namun setelah seorang ahli berkebangsaan Belanda menemukan khasiat yang terdapat dalam air panas alam tersebut untuk menyembuhkan berbagai macam penyakit khususnya penyakit kulit, maka mulailah berdatangan orang dari berbagai daerah untuk datang mandi sambil berobat ke Ciater. Mr. Hack Bessel atau Tuan Bessel dalam mengembangkan penelitiannya (begitulah panggilan akrab masyarakat kepada ahli Belanda itu) membangun rumah tinggal didekat sumber air panas alam Ciater, lokasinya kira-kira disekitar kantor Koperasi Karyawan PT. Sari Ater . Sejak tersiar berita tentang khasiat air panas alam Ciater berdatangan masyarakat lain dari luar daerah Ciater untuk mandi dan berobat. Hanya sayang karena suasana pada waktu itu tidak menentu, sering terjadi kekacauan dan perang maka lambat laun orang melupakan potensi sumber daya alam Jawa Barat yang sangat besar itu. Barulah pada tahun 1968 Pemda Kabupaten Subang melalui PU Kabupaten bekerjasama dengan Dispenda perlahan-lahan mulai menggarap sumber air panas alam Ciater sebagai objek wisata. Pada saat itu baru dibangun 1 buah kolam renang (sekarang dikenal dengan nama kolam renang Mayangsari I atau kolam renang atas dan sebuah kolam kecil yang sekarang bernama kolam Imas serta beberapa buah kamar mandi terbuka.

Sebagai Manager pertama ditetapkan Bapak Sahro dari PU Kabupaten sedangkan jumlah karyawan lebih kurang 11 orang. Pada Tahun 1972 PPN DWIKORA IV (sekarang PTP XIII Ciater) membuat 1 buah bangunan untuk kamar mandi dan pintu gerbang berbentuk joglo yang lengkap dengan kantor dan loket penjualan ticket. Disaat itu pula pembangunan reservoar air dingin yang berlokasi diarea parkir atas sekarang, 1 buah cafe didepan kolam, kamar mandi ditambah 4 unit lagi sedang wisma 
wisata juga dibangun sebanyak 2 unit lagi dengan type ekonomi. Sementara wisma tersebut sekarang dipakai kantor engineering dan storage. Karyawan yang bertugas saat itu berjumlah lebih kurang 21 orang. Pada tanggal 20 Maret 1974 Pemda TK II Kabupaten Subang menyerahkan pengelolaan Objek Wisata Air Panas Ciater kepada PT. Sari Ater yang dipimpin oleh Bapak H.A SOEWARMA. Pada masa Bupati Kepala Daerah TK II Kabupaten Subang dijabat oleh Bapak Letkol Atju Syamsuddin. Manager pertama yang dipercayakan oleh PT. Sari Ater untuk memimpin pengelolaan objek Wisata air panas alam Ciater adalah Bapak Gautama, Alm (tahun 1974 s/d 1975). Jumlah karyawan yang ada pada saat itu lebih kurang 16 orang. Seluruh area wisata seluas 7.335 Ha yang dikelola dibenahi dan dibuatkan pagar pembatas dari kawat berduri. Untuk menunjang pengembangan dan usaha promosi PT. Sari Ater membangun armada Bus dengan salah satu trayek Bandung Subang melalui Ciater sebanyak 16 armada Bus yang bernama Sari Express. Tahun 1975 Bungalow type Standard mulai dibangun sedangkan Manager kedua saat itu adalah Bapak Tirto Sentono, Alm (tahun 1975 s/d 1976) dan jumlah karyawan telah mencapai 60 orang. Pada tahun 1976 dimulai pembangunan Restaurant Dayang Sumbi, Bungalow Kabayan, Sarana Parkir dan Rekreasi Kolam Perahu. Pimpinan pada saat itu dipercayakan kepada Manager ketiga yaitu Bapak J.R. Iskandar, Alm (tahun 1976 s/d 1977.)

Sampai sekarang hotel dan objek wisata air panas alam Sari Ater lebih terkenal dengan sebutan Sari Ater Hot Spring Resort Hotel and Recreation. Pada awalnya tempat wisata air panas alam Ciater yang sekarang lebih dikenal dengan sebutan Sari Ater Hot Spring Resort Hotel dan Rekreasi adalah tempat pemandian yang biasa dipergunakan oleh masyarakat sekitar Desa Ciater, Palasari dan Nagrak. Namun setelah seorang ahli berkebangsaan Belanda menemukan khasiat yang terdapat dalam air panas alam tersebut untuk menyembuhkan berbagai macam penyakit khususnya penyakit kulit, maka mulailah berdatangan orang dari berbagai daerah untuk datang mandi sambil berobat ke Ciater. Mr. Hack Bessel atau Tuan Bessel dalam mengembangkan penelitiannya (begitulah panggilan akrab masyarakat kepada ahli Belanda itu) membangun rumah tinggal didekat sumber air panas alam Ciater, lokasinya kira-kira disekitar kantor Koperasi Karyawan PT. Sari Ater.

Pada tanggal 20 Maret 1974 Pemda TK II Kabupaten Subang menyerahkan pengelolaan Objek Wisata Air Panas Ciater kepada PT. Sari Ater yang dipimpin oleh Bapak H.A Soewarma, pada masa Bupati Kepala Daerah TKII Kabupaten Subang dijabat oleh Bapak Letkol Atju Syamsuddin. Manager pertama yang dipercayakan oleh PT. Sari Ater untuk memimpin pengelolaan objek Wisata air panas alam Ciater adalah Bapak Gautama, Alm (tahun 1974 s/d1975). Seluruh area wisata seluas 7.335 Ha yang dikelola dibenahi dan dibuatkan pagar pembatas dari kawat berduri. Untuk menunjang pengembangan dan usaha promosi PT. SariAter membangun armada bis dengan salah satu trayek Bandung Subang melalui Ciater sebanyak 16 armada bis yang bernama Sari Express. Tahun 2000 Sari Ater Hot Spring Resort membangun kembali Multi Function Room Dayang Sumbi fasilitas ruangan meeting dengan kapasitas 750 sampai 1000 orang. Ruangan tersebut bisa dipakai untuk pernikahan, ulang tahun, seminar dengan 


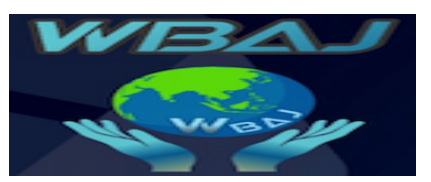

Volume 1 Issue 2, Desember 2019

http://ejournal.unsub.ac.id/index.php/bisnis

beberapa bentuk meeting. Sampai sekarang hotel dan objek wisata air panas alam Sari Ater lebih terkenal dengan sebutan Sari Ater Hot Spring Resort Hotel and Recreation. Sari Ater Hotel $\mathcal{E}$ Resort merupakan perushaan yang kokoh sebagai perusahaan perencana pengembangan dan pengelola usaha jasa industrI pariwisata unggulan dan terpercaya dalam mewujudkan kawasan wisata bertaraf internasional dengan fokus kepada pelayanan bagi para pelanggan dan memenuhi harapan stakeholders. Misi Sariater adalah menjalankan usaha jasa kepariwisataan dan usaha-usaha penunjung lainnya melalui praktek usaha dengan bentuk organisasi profesional yang dapat menyumbang nilai tambah bagi stakeholders serta kelestarian lingkugan berdasarkan 3 (tiga) faktor kepuasan; pelayanan, kenyamanan, dan keselamatan; Menciptakan lapangan pekerjaan yang seluas-luasnya dan memberikan kesempatan usaha kepada masyarakat disekitarnya; Mengembangkan kawasan wisata didaerah-daerah yang dianggap memiliki potensi; Turut serta dalam melestarikan dan mengembangkan seni budaya tradisi masyarakat setempat didaerah yang dikelola; dan Menjaga dan melestarikan lingkungan alam sekitarnya dengan penanganan pengembangan dan pengelolaan yang profesional serta ramah lingkungan.

\section{b. Uji Validitas}

Uji validitas digunakan untuk mengetahui apakah instrumen dari masing-masing dapat digunakan untuk mengukur variabel penelitian. Instrumen dikatakan valid apabila instrumen penelitian mampu mengukur variabel $\mathrm{X}$ dan variabel $\mathrm{Y}$. Tinggi rendahnya validitas insrumen menunjukan sejauh mana data yang terkumpul tidak menyimpang dari gambaran tentang variabel yang dimaksud. Adapun alat pengujian yang dipakai adalah rumus korelasi Product Moment Pearson dengan menggunakan software SPSS ver. 18.00 sebagai berikut:

Tabel 3

Hasil Uji Validitas Variabel Kualitas Pelayanan (X)

\begin{tabular}{|c|c|c|c|}
\hline & R korelasi antara & r tabel & \multirow{2}{*}{ Kesimpulan } \\
\cline { 3 - 3 } butir \& skor & (Batas minimum) & Valid \\
\hline 1 & 0,496 & 0,30 & Valid \\
\hline 2 & 0,468 & 0,30 & Valid \\
\hline 3 & 0,400 & 0,30 & Valid \\
\hline 4 & 0,720 & 0,30 & Valid \\
\hline 5 & 0,567 & 0,30 & Valid \\
\hline 6 & 0,631 & 0,30 & Valid \\
\hline 7 & 0,720 & 0,30 & Valid \\
\hline 8 & 0,420 & 0,30 & Valid \\
\hline 9 & 0,631 & 0,30 & Valid \\
\hline 10 & 0,609 & 0,30 & Valid \\
\hline 11 & 0,610 & 0,30 & Valid \\
\hline 12 & 0,611 & 0,30 & \\
\hline
\end{tabular}

Sumber : Data Primer yang diolah 2019 


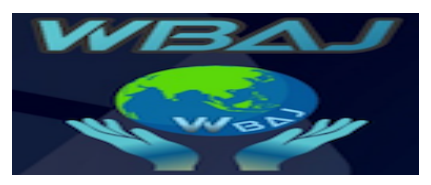

Volume 1 Issue 2, Desember 2019

http:/ / ejournal.unsub.ac.id/index.php/bisnis

Berdasarkan tabel 4.7, hasil uji validitas kualitas pelayanan $(X)$ memperhatikan

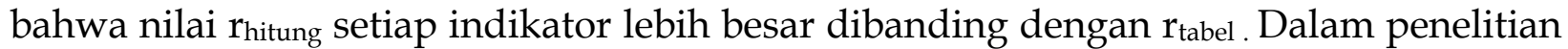
ini peneliti menggunakan 100 responden dengan alpha 0,1, maka diperoleh $r_{\text {tabel }}$ sebesar 0,30, sehingga diperoleh gambaran bahwa uji instrumen untuk variabel kualitas pelayanan menunjukan semua pernyataan 12 item dapat dikatakan valid, karena koefisien yang di hasilkan lebih besar dari 0,30 . Nilai tertinggi adalah pernyataan butir ke 4 dan 7 sebesar 0,720 dan nilai terendah adalah pernyataan butir ke 3 sebesar 0,400, sehingga semua data bisa diajukan ke analisis berikutnya.

Uji Validitas Untuk Variabel Loyalitas Pelanggan (Y), hasil perhitungannya dapat dijelaskan pada tabel 4.8 sebagai berikut:

Tabel 4

Hasil Uji Validitas Variabel Loyalitas Pelanggan (Y)

\begin{tabular}{|c|c|c|c|}
\hline Item & $\begin{array}{c}\text { R korelasi } \\
\text { antara butir \& } \\
\text { skor }\end{array}$ & $\begin{array}{c}\text { r tabel } \\
\text { (Batas } \\
\text { minimum) }\end{array}$ & Kesimpulan \\
\hline 1 & 0,379 & 0,30 & Valid \\
\hline 2 & 0,814 & 0,30 & Valid \\
\hline 3 & 0,728 & 0,30 & Valid \\
\hline 4 & 0,554 & 0,30 & Valid \\
\hline 5 & 0,578 & 0,30 & Valid \\
\hline 6 & 0,577 & 0,30 & Valid \\
\hline 7 & 0,570 & 0,30 & Valid \\
\hline 8 & 0,387 & 0,30 & Valid \\
\hline
\end{tabular}

\section{Sumber : Data Primer yang diolah 2019}

Berdasarkan tabel 4.8, hasil uji validitas loyalitas pelanggan $(\mathrm{Y})$ memperhatikan

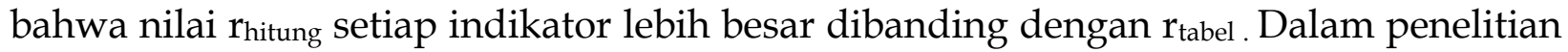
ini peneliti menggunakan 100 responden dengan alpha 0,1, maka diperoleh $\mathrm{r}_{\text {tabel }}$ sebesar 0,30, sehingga diperoleh gambaran bahwa uji instrumen untuk variabel loyalitas pelanggan menunjukan semua pernyataan 8 item_dapat dikatakan valid, karena koefisien yang di hasilkan lebih besar dari 0,30 . Nilai tertinggi adalah pernyataan butir ke 2 sebesar 0,814 dan nilai terendah adalah pernyataan butir ke 1 sebesar 0,379, sehingga semua data bisa diajukan ke analisis berikutnya.

\section{c. Uji Reliabilitas}

Uji reliabilitas bertujuan untuk menunjukan sejauh mana suatu hasil pengukuran relatif konsisten apabila pengukuran diulangi dua kali atau lebih. Jadi dengan kata lain bahwa reliabilitas adalah indeks yang menunjukan sejauh mana suatu alat ukur dapar dipercaya atau dapat diandalkan, bila alat pengukur tersebut digunakan dua kali atau lebih untuk mengukur gejala yang sama, dan hasil pengukuran yang diperoleh relatif konsisten.

Setiap instrumen harusnya memiliki kemampuan untuk memberikan hasil pengukuran yang konsisten, sehingga hasil pengukuran dapat dipercaya hanya apabila 


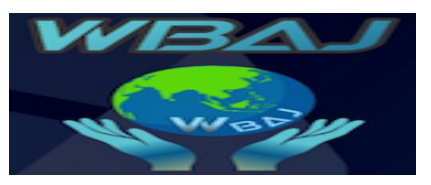

Volume 1 Issue 2, Desember 2019

http://ejournal.unsub.ac.id/index.php/bisnis

dalam beberapa kali pengukuran terhadap kelompok subyek yang sama diperoleh hasil yang relatif sama, selama prinsip yang diukur dalam diri subyek memang belum berubah. Untuk menghitung koefisien reliabilitas, Alfa Cronbach dalam Sugiyono (2013:365) menggunakan rumus sebagai berikut:

\begin{tabular}{|c|c|c|}
\hline & $r=\left(\frac{k}{k-1}\right)\left(1-\frac{\sum V_{i}}{V_{t}}\right)$ & \\
\hline $\begin{array}{l}\text { Menurut Sekaran } \\
\text { kurang dari } 0,6 \text { adalah } \\
0,7 \text { dapat diterima dan }\end{array}$ & $(k-1)\left(v_{t}\right)$ & $\begin{array}{l}(2003: 73) \text {, jika reliabilitas } \\
\text { kurang baik, sedangkan } \\
\text { diatas } 0,8 \text { adalah baik. }\end{array}$ \\
\hline
\end{tabular}

Berdasarkan hasil perhitungan rumus Alfa Cronbach dengan menggunakan software SPSS ver. 18.00, maka diperoleh keputusan koefisien reliabilitas dari penelitian sebagai berikut:

Tabel 5

Hasil Uji Reliabilitas Instrumen Penelitian

Reliability Statistics

\begin{tabular}{|r|r|r|}
\hline Cronbach's Alpha & $\begin{array}{c}\text { Cronbach's Alpha Based } \\
\text { on Standardized Items }\end{array}$ & N of Items \\
\hline, 867 &, 885 & 20 \\
\hline
\end{tabular}

Berdasarkan tabel 4.9, menunjukan bahwa variabel penelitian mempunyai nilai reliabilitas 0,867 yang berarti berada diatas 0,8 maka bisa dikatagorikan reliabilitas baik, maka uji reliabilitas tersebut dinyatakan reliabel. Keputusan hasil uji reliabilitas ini menunjukan bahwa seluruh instrumen yang digunakan untuk mengukur seluruh item dari variabel kualitas pelayanan dan loyalitas pelanggan, sebagaimana telah dioperasionalisasikan pada operasional variabel dapat diterima keterandalan atau kekonsistensiannya.

\section{d. Hasil Pengujian Hubungan (Asosiatif)}

Pengujian hubungan (asosiatif) untuk melihat ada atau tidak adanya hubungan kualitas pelayanan terhadap loyalitas pelanggan pada Sari Ater Hotel \& Resort Subang. Maka, sebelumnya telah diajukan hipotesis sebagai berikut: "Terdapat Pengaruh Kualitas Pelayanan terhadap Loyalitas Pelanggan pada Sari Ater Hotel \& Resort Subang".

Pengujian hubungan antara kualitas pelayanan terhadap loyalitas pelanggan dicari berdasarkan hasil pengujian software SPSS ver. 18.00 dan menggunakan rumus koefisien korelasi. Statistik uji ini dipilih berdasarkan bentuk data diolah berskala ordinal kemudian dikonversi ke data interval.

Berdasakan hasil perhitungan dengan menggunakan software SPSS ver. 18.00 dapat dihasilkan dalam bentuk tabel sebagai berikut:

\section{Tabel 6}

Pengujian Hubungan (Asosiatif)

Correlations 


\begin{tabular}{|ll|r|r|}
\hline & \multicolumn{1}{|c|}{$\begin{array}{c}\text { Kualitas } \\
\text { pelayanan }\end{array}$} & $\begin{array}{c}\text { Loyalitas } \\
\text { Pelanggan }\end{array}$ \\
\hline $\begin{array}{l}\text { Kualitas } \\
\text { pelayanan }\end{array}$ & Pearson & 1 &, $839^{* *}$ \\
& Correlation & & \\
& Sig. (2-tailed) & 100 &, 000 \\
& $\mathrm{~N}$ &, $839^{* *}$ & 100 \\
\hline Loyalitas & Pearson & & \\
Pelanggan & Correlation &, 000 & \\
& Sig. (2-tailed) & 100 & 100 \\
& $\mathrm{~N}$ &
\end{tabular}

**. Correlation is significant at the 0.01 level (2-tailed).

Berdasarkan tabel 4.10, dapat dijelaskan bahwa antara variabel kualitas pelayanan terhadap loyalitas pelanggan pada Sari Ater Hotel \& Resort Subang "sangat kuat" dengan nilai 0,839 sebagaimana dikemukakan Sugiono (2013:184) nilai tersebut berada pada interval koefisien 0,800-1,000.

\section{e. Analisis Regresi Linier Sederhana}

Analisis regresi digunakan untuk melihat pengaruh kualitas pelayanan terhadap loyalitas pelanggan, dengan demikian diketahui persamaan regresi berdasarkan perhitungan dengan menggunakan software SPSS ver. 18.00 dapat dilihat dalam bentuk tabel 4.11 sebagai berikut:

Tabel 7

Analisis Regresi Linier Sederhana

Coefficients $^{\mathrm{a}}$

\begin{tabular}{|c|c|c|c|c|c|}
\hline \multirow[t]{2}{*}{ Model } & \multicolumn{2}{|c|}{$\begin{array}{c}\text { Unstandardized } \\
\text { Coefficients }\end{array}$} & \multirow{2}{*}{$\begin{array}{c}\begin{array}{c}\text { Standardize } \\
\mathrm{d} \\
\text { Coefficients }\end{array} \\
\text { Beta }\end{array}$} & \multirow[b]{2}{*}{$\mathrm{t}$} & \multirow[b]{2}{*}{ Sig. } \\
\hline & $B$ & Std. Error & & & \\
\hline \begin{tabular}{|ll}
1 & (Constan \\
& $\mathrm{t})$ \\
& Kualitas \\
& pelayana \\
& $\mathrm{n}$
\end{tabular} & $\begin{array}{r}2,788 \\
, 573\end{array}$ & $\begin{array}{r}1,900 \\
, 038\end{array}$ & 839 & $\begin{array}{r}1,467 \\
15,252\end{array}$ & $\begin{array}{l}\text {, 146 } \\
\text {,000 }\end{array}$ \\
\hline
\end{tabular}

a. Dependent Variable: Loyalitas Pelanggan

Berdasarkan tabel 4.11 diatas, dapat dijelaskan bahwa persamaan regresi antara kualitas pelayanan terhadap loyalitas pelanggan dapat disusun sebagai berikut:

$\mathrm{Y}=\mathrm{a}+\mathrm{bX}$

$Y=2,788+0,573 X$

Dimana : 


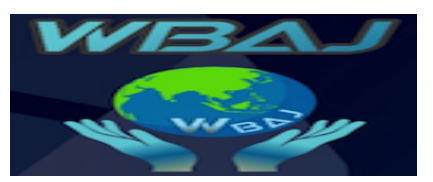

Volume 1 Issue 2, Desember 2019

http:/ / ejournal.unsub.ac.id/index.php/bisnis

$X=$ Kualitas Pelayanan

$\mathrm{Y}=$ Loyalitas Pelanggan

$\mathrm{a}=$ nilai konstanta yang menunjukan bahwa jika tidak ada kualitas pelayanan maka loyalitas pelanggan akan mencapai nilai sebesar 2,788.

$\mathrm{b}=$ koefisien regresi sebesar 0,573 artinya setiap penambahan atau peningkatan kualitas pelayanan $1 \%$, maka loyalitas pelanggan juga akan meningkat sebesar $0,573 \mathrm{X}$

\section{f. Uji Regresi (Parameter ) Secara Parsial (Uji t)}

Uji regresi (parameter ) secara parsial (uji t) digunakan untuk menguji signifikansi pengaruh antara dua variabel, untuk itu harus dites apakah korelasi antara variabel kualitas pelayanan $(\mathrm{X})$ dengan variabel loyalitas pelanggan $(\mathrm{Y})$ signifikan atau tidak, maka perlu dilakukan pengujian uji $t$, dengan menggunakan tingkat signifikan 0,1 sebagai berikut :

$\mathrm{H}_{0}: \mathrm{P}=0 \quad$ : Tidak Terdapat Pengaruh antara Kualitas Pelayanan terhadap Loyalitas Pelanggan pada Sari Ater Hotel \& Resort Subang. $\mathrm{H}_{\mathrm{a}}: \mathrm{P} \neq 0$ : Terdapat Pengaruh antara Kualitas Pelayanan terhadap Loyalitas Pelanggan pada Sari Ater Hotel \& Resort Subang.

Hasilnya Jika $\mathrm{t}$ hitung $>\mathrm{t}$ tabel maka $\mathrm{H}_{0}$ ditolak atau $\mathrm{H}_{\mathrm{a}}$ diterima. Perhitungan uji hipotesis ini menggunakan software SPSS ver. 18.00.

Berdasarkan tabel 4.11, diperoleh $\mathrm{t}$ hitung sebesar 15,525 dan selanjutnya menentukan $\mathrm{t}$ tabel tabel distribusi $\mathrm{t}$ dicari pada $=0,1$ dengan derajat bebas $\mathrm{N}-2$ yaitu $100-2=98$, maka $t$ tabel diperoleh 1,661. Oleh karena itu $t$ hitung lebih besar dari $t$ tabel yaitu 15,525 > 1,661. Maka $\mathrm{H}_{0}$ ditolak, artinya terdapat pengaruh antara kualitas pelayanan terhadap loyalitas pelanggan pada Sari Ater Hotel $\mathcal{E}$ Resort Subang atau dengan kata lain variabel kualitas pelayanan $(X)$ memberikan pengaruh positif terhadap variabel loyalitas pelanggan $(\mathrm{Y})$.

\section{g. Analisis Koefisien Determinasi}

Analisis koefisien determinasi digunakan untuk mengetahui besarnya pengaruh kualitas pelayanan terhadap loyalitas pelanggan. Hasil perhitungan koefisien determinasi melalui software SPSS ver. 18.00 dapat dilihat dalam tabel sebagai berikut:

Tabel 4.12

Hasil Perhitungan Koefisien Determinasi

Model Summary ${ }^{b}$

\begin{tabular}{|l|l|l|l|l|l|}
\hline $\begin{array}{l}\text { Mod } \\
\text { el }\end{array}$ & $\mathrm{R}$ & $\begin{array}{c}\mathrm{R} \\
\text { Square }\end{array}$ & $\begin{array}{c}\text { Adjusted R } \\
\text { Square }\end{array}$ & $\begin{array}{c}\text { Std. Error } \\
\text { of the } \\
\text { Estimate }\end{array}$ & $\begin{array}{l}\text { Durbin- } \\
\text { Watson }\end{array}$ \\
\hline
\end{tabular}




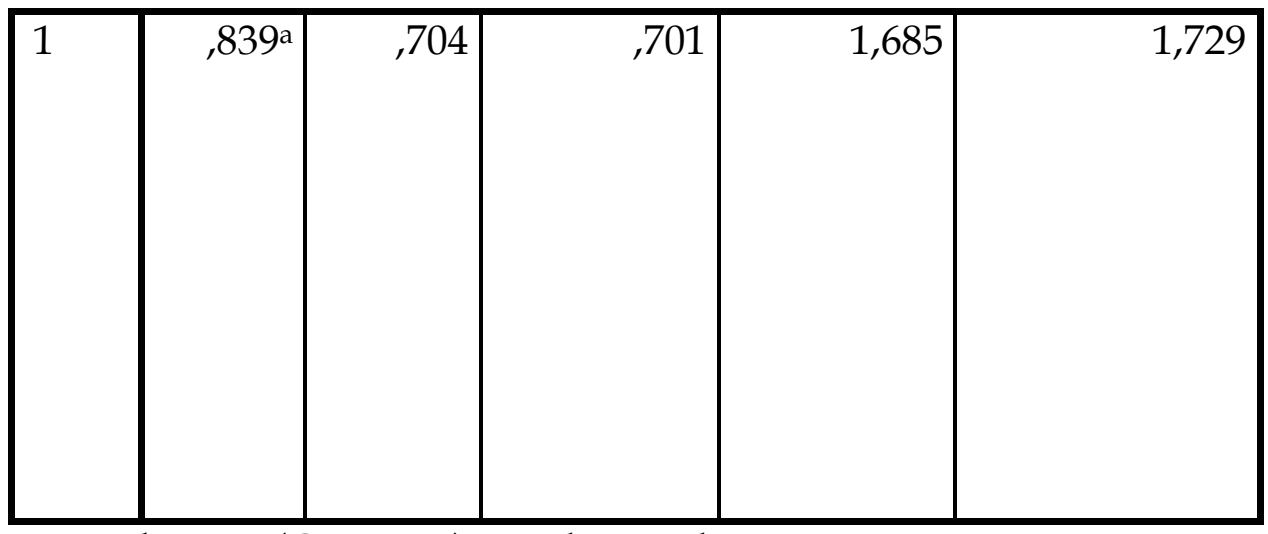

a. Predictors: (Constant), Kualitas Pelayanan

b. Dependent Variable: Loyalitas Pelanggan

Berdasarkan tabel 4.12 diatas, nilai $R$ sebesar 0,839 menunjukan bahwa terdapat hubungan yang kuat antara kualitas pelayanan terhadap loyalitas pelanggan. Sedangkan nilai $\mathrm{R}$ Square atau $\mathrm{r}^{2}$ merupakan koefisien determinasi atau koefisien penentu.

Dari tabel diatas, nilai R Square sebesar 0,704 atau 0,704 x 100\% = 70,4\% yang berati bahwa variabel independen (kualitas pelayanan) mempengaruhi variabel dependen (loyalitas pelanggan) sebesar 70,4\% dan sisanya 29,6\% yang diperkirakan dipengaruhi oleh faktor lain. Faktor yang tidak diteliti lebih lanjut oleh peneliti dapat diteliti oleh peneliti lain sebagai acuan untuk diteliti dan dikembangkan lagi.

Secara nyata berdasarkan hasil penelitian menunjukan bahwa secara statistik bahwa variabel $X$ terhadap variabel $Y$ lebih sesuai dengan hipotesis yang telah dikemukakan. Dari data pengujian hipotesis sebelumnya, dapat disimpulkan bahwa hipotesis pertama yaitu memperoleh pengaruh kualitas pelayanan terhadap loyalitas pelanggan terdukung. Hal ini menunjukan bahwa kualitas pelayanan merupakan faktor penting yang dapat mempengaruhi loyalitas pelanggan. Hubungan pelayanan yang baik antara karyawan kepada pelanggan, fasilitas yang disediakan sesuai dengan harapan pelanggan yang berhubungan dengan loyalitas pelanggan. Semakin baik pelayanan yang diberikan kepada pelanggan maka pelanggan akan lebih loyal terhadap suatu perusahaan. Berdasarkan hasil SPSS ver. 18.00 menunjukan bahwa adanya hubungan yang kuat antara kualitas pelayanan terhadap loyalitas pelanggan dengan hasil $t$ hitung lebih besar dari $t$ tabel yaitu 15,525 >1,661.

Jadi kesimpulannya, terdapat hubungan yang kuat dan signifikan antara kualitas pelayanan dan loyalitas pelanggan Sari Ater Hotel \& Resort Subang. Jika kualitas pelayana yang diberikan baik dan maksimal, maka loyalitas pelanggan pun akan terjalin dengan baik. Untuk menghitung seberapa besar pengaruh kualitas pelayanan $(\mathrm{X})$ terhadap loyalitas pelanggan $(\mathrm{Y})$, berdasarkan hasil uji koefisien determinasi menunjukan nilai R Square sebesar 0,704 atau 0,704 x 100\% $=70,4 \%$ yang berarti bahwa variabel independent (kualitas pelayanan) mempengaruhi variabel dependent (loyalitas 


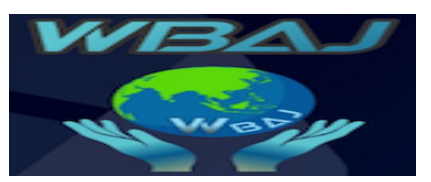

Volume 1 Issue 2, Desember 2019

http://ejournal.unsub.ac.id/index.php/bisnis

pelanggan) sebesar 70,4\% dan sisanya 29,6\% yang diperkirakan dipengaruhi oleh faktor lain. Faktor yang tidak diteliti lebih lanjut oleh peneliti dapat diteliti oleh peneliti lain sebagai acuan untuk diteliti dan dikembangkan lagi. Dengan demikian dapat diketahui bahwa peran kualitas pelayanan merupakan faktor penting dalam menentukan loyalitas pelanggan. Dimana Sari Ater Hotel $\mathcal{E}$ Resort Subang sangat memperhatikan kualitas pelayanan dengan memenuhi kebutuhan pelanggan.

\section{Kesimpulan}

Berdasarkan hasil analisis data dan informasi yang diperoleh sebagaimana dijelaskan pada bab sebelumnya dan didukung oleh hasil kuesioner, maka dapat disimpulkan sebagai berikut:

a) Variabel Kualitas Pelayanan pada Sari Ater Hotel $\mathcal{E}$ Resort Subang cukup tinggi. Mayoritas jawaban responden adalah menyatakan setuju sebanyak $52 \%$ bahwa kualitas pelayanan pada Sari Ater Hotel $\mathcal{E}$ Resort Subang sesuai dengan yang diharapkan pelanggan.

b) Variabel Loyalitas Pelanggan pada Sari Ater Hotel \& Resort Subang berdasarkan hasil jawaban 100 orang responden menghasilkan jawaban yang variatif, mulai dari jawaban negatif, ragu-ragu hingga positif. Jawaban didominasi dengan responden yang menyatakan setuju sebanyak $61 \%$.

c) Dalam penelitian ini memperlihatkan pengaruh Kualitas Pelayanan terhadap Loyalitas Pelanggan dengan metode regresi linier sederhana memberikan hasil pengujian yang signifikan pada taraf signifikan sebesar $10 \%$ mempengaruhi loyalitas pelanggan $70,4 \%$ dan $29,6 \%$ di pengaruhi oleh faktor lain yang tidak di teliti oleh penuis. Dengan demikian dapat disimpulkan bahwa kualitas pelayanan berpengaruh secara signifikan terhadap loyalitas pelanggan. Kualitas pelayanan menjadi faktor penting dalam menciptakan loyalitas pelanggan. Kualitas pelayanan secara langsung mempengaruhi loyalitas pelanggan.

\section{Referensi}

Alma, Buchori. 2007. Manajemen Pemasaran Jasa. Bandung: CV Alfabeta.

Alma, Buchori. 2013. Pengertian Bisnis. Bandung: CV Alfabeta.

Arief, M. 2007. Pemasaran Jasa \& Kualitas Pelayanan: Bagaimana mengelola Kualitas Pelayanan agar Memuaskan Pelanggan. Malang: PT Bayu Media Publising.

Fajar, Rizky. 2009. Pengaruh Kualitas Pelayanan terhadap Loyalitas Pelanggan. Universitas Sebelas Maret Surakarta.

Griffin, Jill. 2005. Custemer Loyality: Menumbuhkan Dan Mempertahankan Kesetiaan Pelanggan. Jakarta: Erlangga. 


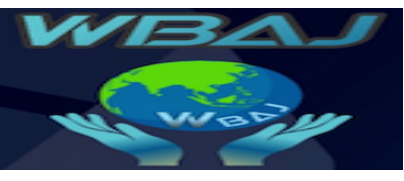

Volume 1 Issue 2, Desember 2019

http://ejournal.unsub.ac.id/index.php/bisnis

Kotler, Philip. 2005. Manajemen Pemasaran, jilid 1 dan 2. Jakarta: Indeks Kelompok Gramedia.

Kotler, P. \& Keller, K. L. 2009. Manajemen Pemasaran, jilid 1 edisi 13. Jakarta: Erlangga.

Silalahi, Ulbert . 2013. Studi tentang Ilmu Administrasi. Bandung: Sinar Baru Algensindo.

Sugiono. 2007. Metode Penelitian Bisnis. Bandung: Alfabeta.

Sugiono. 2014. Metode Penelitian Bisnis. Bandung: Alfabeta.

Susepti, Amalia. 2017. Pengaruh Kualitas Pelayanan terhadap Loyalitas Tamu Hotel pada Hotel Mahkota Plengkung Kabupaten Banyuwangi. Universitas Brawijaya Malang.

Tjiptono, Fandy. 2004. Pemasaran Jasa. Malang: Bayumedia.

Tjiptono, Fandy. 2014. Pemasaran Jasa. Yogyakarta: ANDI.

Tjiptono, Fandy dan Gregorius Candra. 2016. Service Quality dan Statisfaction. Yogyakarta: ANDI. 